ENTREPRENEURSHIP AND SUSTAINABILITY ISSUES

ISSN 2345-0282 (online) http://jssidoi.org/jesi/

2019 Volume 6 Number 4 (June)

http://doi.org/10.9770/jesi.2019.6.4(19)

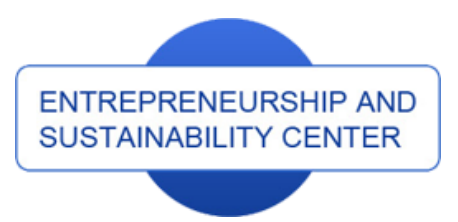

Publisher

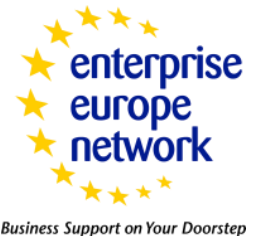

CASPA

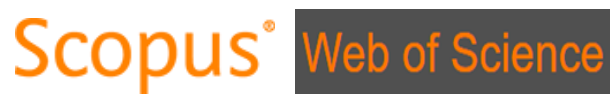

http://jssidoi.org/esc/home

Business Support on Your Doorstep

1) Clarivate

Analytics

\title{
INTEGRATED QUALITY MANAGEMENT SYSTEM FOR FOOD PRODUCTION: A CASE OF DAIRY PRODUCTS' ENTERPRISE
}

\author{
Saule Ospandiyarovna Akhmetova ${ }^{1}$, Lyazzat Kemerbekovna Baibolova ${ }^{2}$, \\ Mira Serikovna Serikkyzy ${ }^{3}$ \\ 1,2,3 Almaty Technological University, Tole bi street 100, Almaty 050012, Republic of Kazakhstan \\ E-mails: ${ }^{1}$ sunrise_kz@mail.ru; ${ }^{2}$ l.baybolova@atu.kz; ${ }^{3}$ mira.serikkyzy@mail.ru
}

Received 15 March 2018; accepted 10 July 2018; published 30 June 2019

\begin{abstract}
The article presents results of the researches on creation of integrated quality management system for food enterprise reflecting branch specifics in a basis of the international ISO standards of series 9000 and the principles of HACCP. Theoretical and practical aspects of construction and development of systems of QMS and HACCP are analysed and the technique of creation of the integrated quality management system (IQMS) of the Raimbek Agro Company is offered. Degrees of compatibility of the international ISO 9001:2015 standard (ST RK ISO 9001-2016) and the principles of HACCP (ST RK 1179-2003) are defined. The conceptual model of the IQMS is offered. Areas of integration of HACCP and QMS systems are also established and the additive model of creation of the IQMS is chosen. The network of the processes of the IQMS of the Raimbek Agro Company on the basis of the carried-out processes integration is created.
\end{abstract}

Keywords: QMS (quality management system); process approach; HACCP (Hazard Analysis and Critical Control Point); IQMS (Integrated Quality Management System); dairy products.

Reference to this paper should be made as follows: Akhmetova, S.O.; Baibolova, L.K., Serikkyzy, M.S., 2019. Integrated quality management system for food production: a case of dairy products' enterprise, Entrepreneurship and Sustainability Issues 6(4): 1807-1822. http://doi.org/10.9770/jesi.2019.6.4(19)

JEL Classifications: Q01, Q14

Additional disciplines: food technology, ecology 


\section{ENTREPRENEURSHIP AND SUSTAINABILITY ISSUES}

ISSN 2345-0282 (online) http://jssidoi.org/jesi/

2019 Volume 6 Number 4 (June)

http://doi.org/10.9770/jesi.2019.6.4(19)

\section{Introduction}

In present time the modern enterprises of various industries are forced to function in conditions of high complexity and dynamism of social and economic environment. In modern market conditions, the stable and successful activity of an enterprise is defined by a number of factors, the basic of which is the ability to satisfy the needs of the consumer with high-quality and safe products. It is possible to be kept in the market only at existence of real high-organized competitive advantages and for this purpose it is needed to have the perfect organization of work of the enterprise.

A variety of management systems and the standards are used during their creation, constantly growing and covering various fields of the company activity. Thus, now management systems represent the effective tool by means of which organizations can optimumally build their activity according to the modern requirements constantly amplifying in the conditions of competition. In documents, establishing requirements to the management systems, is generalized international experience of system management of quality, ecology, personnel, labor protection and industrial safety, information support of systems, etc.

Quality management system is that part of the general management system at the company which functions with the purpose of ensuring stable quality of products or services. Quality management systems occupy the special place among all existing management systems, since they are one of the latest achievements in the area of the quality problems solution at any organization (Conti, T., 2005; Maximov and Papkov, 2003; Alymbekov K.A., 2003; Chris Bamber, John Sharp, Mick Hides, 2002).

As it was noted in the article of the main author (Akhmetova, S.O., Fuschi, D. L., Vasiliūnaite, R., 2017), the development of integrated management systems considering the specific features of the enterprises when focusing on concrete branches of the industry, in particular its modification in food industry is of special interest.

For integration of quality management it is important to provide an effective management of the processes operating at the enterprise. It is caused by the fact that the quality directly depends on efficiency of these processes and operations making them, on the organization of information streams between processes and operations in the course of creation of products. Therefore, the quality in the mode of real time is defined by control of processes, the applied techniques and work of personnel (Watkins David K., 2006).

"Integration" is a process of mutual adaptation, expansion of economic and production cooperation. "Under the integrated management system, (M.Z. Svitkin) should be understood as part of the general management of the organization meets two or more international standards for management systems and functioning as uniform whole" (Svitkin M.Z., 2004).

In a real situation there is always a set of the factors capable to render influence on integration of management systems of the organization. It is possible to identify as such the factors following:

1 Harmonization of the purposes and objectives; at statement of the purposes and objectives it is necessary to consider expediency of the accepted decision, i.e. to correlate expenses to estimated profit;

2 The distribution of priorities in the organization affecting degree and depth of systems integration;

3 Existence of management system which is already operating at the enterprise; 


\section{ENTREPRENEURSHIP AND SUSTAINABILITY ISSUES}

ISSN 2345-0282 (online) http://jssidoi.org/jesi/

2019 Volume 6 Number 4 (June)

http://doi.org/10.9770/jesi.2019.6.4(19)

4 Requirements and expectations of stakeholders;

5 The structure of systems: for example, the uniformity of management systems (identity of structural elements and proximity of nature of their interrelation) promotes integration;

6 Requirements of improvement of efficiency and effectiveness of management can act as the factor promoting integration of systems;

7 Stability of organizational structure of the enterprise (Chris Bamber, John Sharp, Mick Hides, 2002; Tvaronavičienė M., Tarkhanova E., Durglishvili N., 2018).

The principle of systemacity is one of the main principles on which quality management is based. Management of the interconnected processes as a system improves effectiveness and efficiency of activity of organizations at achievement of purposes (Rodionova Yu.A., 2013).

2 Assessment of functioning of quality management system for food enterprise and development of the strategic solutions for development of management system (Literature Review)

A subject of this research are theoretical and practical aspects of management of enterprise activity introducing integrated quality management system on a basis of modern methods of quality management with use of the system analysis, process approach, a method of expert estimates, analysis of the production practice which developed at the enterprise. An object of a research is the functioning quality management system of Kazakhstan enterprise for production of dairy products Raimbek Agro Company (Akhmetova, S.O., Fuschi, D. L., Vasiliūnaitè, R., 2017).

The ISO standards of series 9000 are a universal basis for creation of quality management system in any organization, independent of the area of activity, applied technologies, qualification and number of employees, and also of other features (Lafta J.K., 2007; Edda Saunders, Ray Saunders, 2005).

But, the universality of standards has also the hidden side. It does not allow to consider the features of a number of the branches of industry where requirements for quality, safety, environmental friendliness are high, therefore, in this situation application of requirements of ISO standards of series 9000 is insufficient. In this regard standards gained branch specifics and on their basis the systems of standards for application in the concrete industries were developed. Use of these standards allows to create the effective system of quality management at concrete industrial sector (Shalayev A.P., 2006; Avstriyevsky A.N., Kantare V.M., Surkov I.V., 2007). In the table 1 the standards applied at food industry are presented (Akhmetova, S.O., Omarova, A.A., 2014). 
Table 1. The Branch (food industry) Quality Management System on a base of ISO International Standards of series 9000.

\begin{tabular}{|c|c|c|c|c|}
\hline 1 & 2 & 3 & 4 & 5 \\
\hline $\begin{array}{l}\text { Quality } \\
\text { Management } \\
\text { System for Food } \\
\text { Industry }\end{array}$ & $\begin{array}{l}\text { International ISO } \\
22000: 2018 \text { Standard } \\
\text { «Food safety } \\
\text { management systems - } \\
\text { Requirements for any } \\
\text { organization in the food } \\
\text { chain» }\end{array}$ & 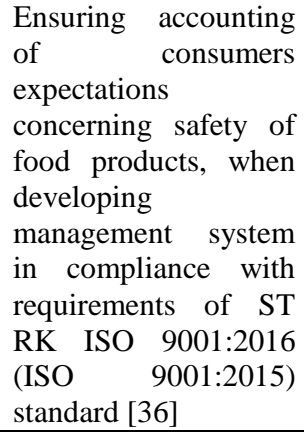 & $\begin{array}{l}\text { ISO } 22000: 2018 \text { standard } \\
\text { dynamically unites the } \\
\text { principles and practice of } \\
\text { HACCP with programs of } \\
\text { preliminary conditions, } \\
\text { using the analysis of risks } \\
\text { for definition of the strategy } \\
\text { providing risk management } \\
\text { and coordination of } \\
\text { programs of preliminary } \\
\text { conditions with the plan of } \\
\text { HACCP [69]. }\end{array}$ & $\begin{array}{l}\text { Complex application of } \\
\text { two standards will } \\
\text { become for } \\
\text { manufacturers an } \\
\text { effective instrument for } \\
\text { production safe food } \\
\text { products, meeting } \\
\text { requirements of the } \\
\text { legislation, consumers } \\
\text { and manufacturers [69]. }\end{array}$ \\
\hline
\end{tabular}

Realization of the process approach at the enterprise for production of dairy products "Raimbek Agro" LLP has made it possible to strengthen the relations between divisions of the enterprise and to create a basis for the analysis of processes (Akhmetova, S.O., Fuschi, D. L., Vasiliūnaite, R., 2017). In the present time each process participant can obtain full information on all processes and their interrelations in their workplace.

In this case, he or she has an opportunity to do offers on improvements of process which participant he or she is. On a basis of such experience the highest management received an opportunity more deeply to estimate the costeffectiveness for time and resources. The executed work helped to create the required base for definition of priorities of improvement of the enterprise activity. In the new conditions the routine and perspective planning is provided and the enterprise works as a sophisticated mechanism.

The systematic analysis of quality management system from the management, an assessment of its productivity, suitability and opportunity for improvement is one of requirements of the ISO 9001-2015 standard by means of which the principle of quality management - decision-making based on facts - is enabled to realize (ST RK ISO 9001-2016). For the purpose of providing this requirement and realisation of the specified principle the technique of the assessment of productivity of quality management system was developed. The operative procedure for the assessment of productivity of QMS according to the developed technique is reported in fig. 1. 


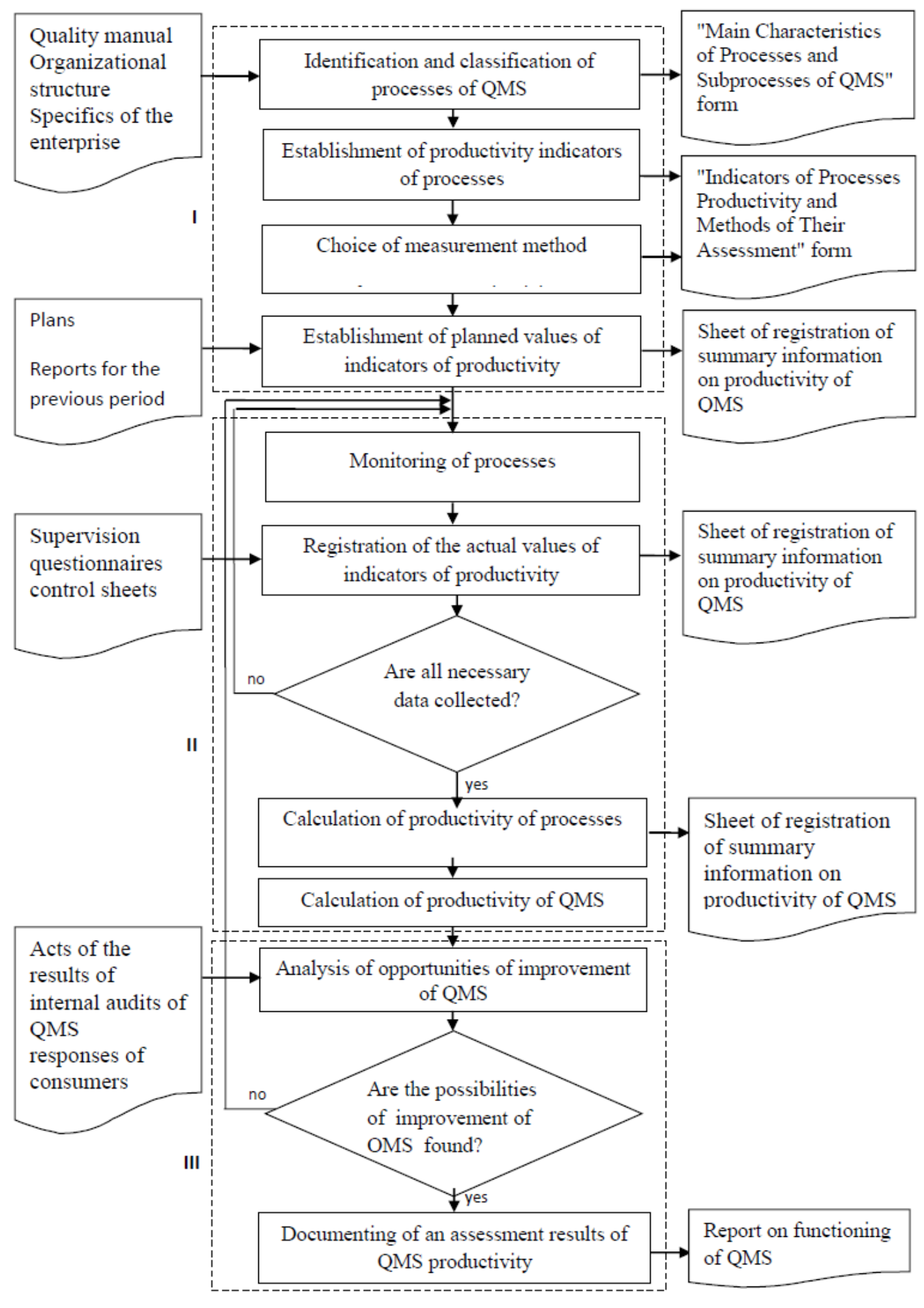

Figure 1. Algorithm of a Technique of Assessment of Productivity and Continuous Improvement of QMS Source: composed by the authors 
In light of the process approach the QMS represents itself as a network of the interconnected processes, therefore the assessment of it productivity is reduced to the assessment of the productivity of the processes and an initial stage of the assessment is the identification and classification of the processes depending on their role in the QMS.

Measurement processes in QMS are the most difficult tasks in practical application. Depending on the processes features different methods of measurement can be used: sociological, expert, comparisons, settlement and tool (fig. 2).

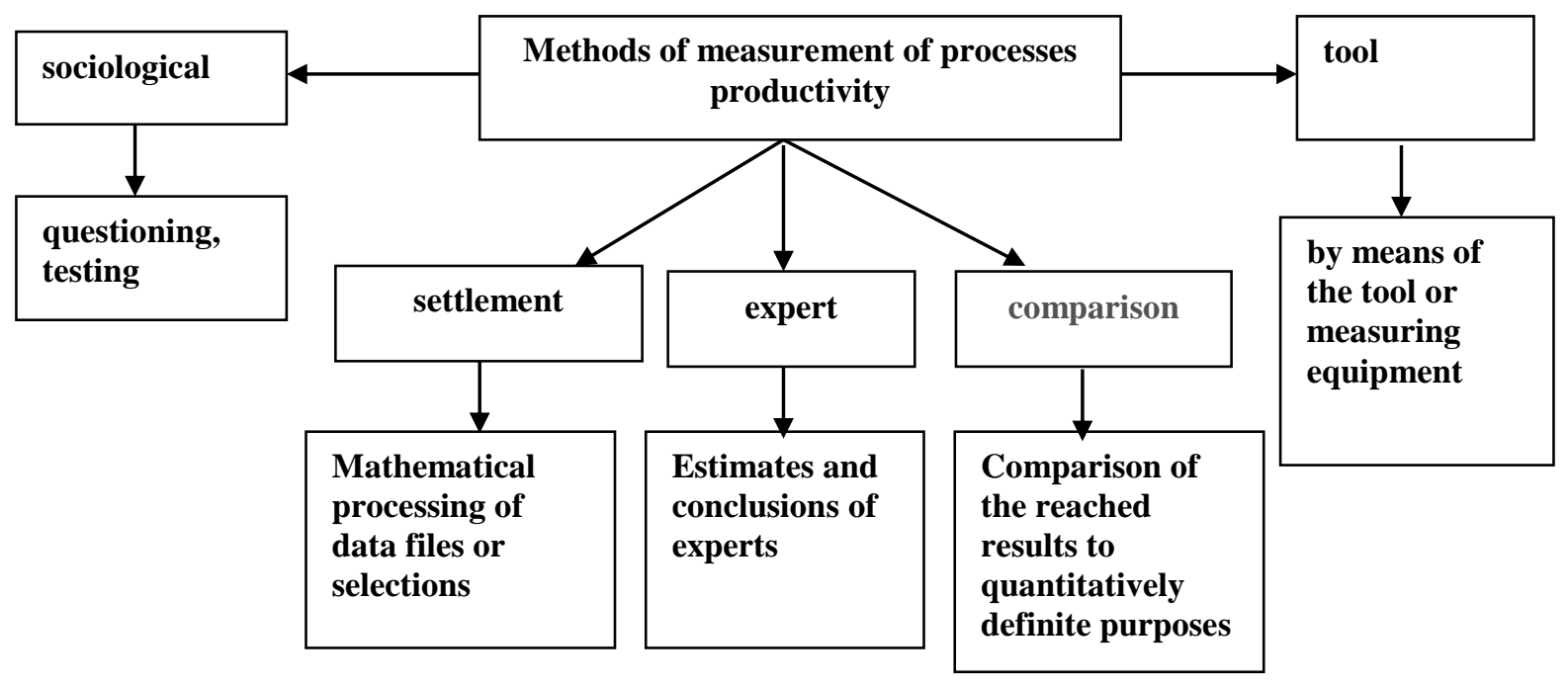

Figure 2. Methods of measurement of processes productivity Source: composed by the authors

As a result of the carried-out work indicators of productivity and methods of their measurement were established (Akhmetova, S.O., Fuschi, D. L., Vasiliūnaite, R., 2017). A technique for the assessment of productivity and continuous improvement of QMS, on the basis of which the analysis of functioning of Raimbek Agro Company QMS, has been developed and implemented. The technique allowed establishing a cause and effect relationships between the planned and reached results. Updating of the document "Process model of Raimbek Agro LLP" has become a final result of this work.

Regular estimation of a condition of the enterprise processes functioning, the fullest accounting of the factors affecting results of processes the continuous analysis of planned values of processes results promote increase in effectiveness of QMS and the organization in a whole.

Assessment of productivity of QMS, the analysis of performance of the warning and adjusting actions planned by the results of it functioning and further planning of improvement of the QMS provide continuous improvement of the enterprise activity. Thus, the possibility of acceptance of operational measures for achievement of the planned results and to correct the purposes already at intermediate stages of planning by adopting the principle of achieving the most possible result but not of real approachability is provided.

Assessment of functioning of the enterprise management system is an initial stage of formation of development strategy of the enterprise management system. In the present time assessment of functioning of "Raimbek Agro" 


\section{ENTREPRENEURSHIP AND SUSTAINABILITY ISSUES}

ISSN 2345-0282 (online) http://jssidoi.org/jesi/

2019 Volume 6 Number 4 (June)

http://doi.org/10.9770/jesi.2019.6.4(19)

LLP management system is based on assessment of QMS productivity which includes collecting and analysis of information of processes functioning. The final stage is development of development strategy of management system of the enterprise which considers the circumstances reflecting changes in the external environment and degree of adequacy to this medium of the enterprise profile, and also the results connected to a new vision of the enterprise.

Thus, the formation of the development strategy of management system based on assessment of its functioning and the comprehensive analysis of the obtained data promotes improvement of diagnostic culture of the enterprise, gradually developing abilities of people to understand communications between system factors, processes and results, involving them in active participation in the choice and realization of strategy. The strategy developed with accounting of requirements of the interested parties is directed to maintenance of such relationship of the enterprise with the external environment which allows it to reach the purposes, correspond to internal opportunities and do it susceptible to external requirements.

On the basis of the comprehensive analysis of the obtained data and the assessment of QMS functioning, an enterprise development strategy focused on the satisfaction of the requirements of all interested parties was developed. One of the key directions of the enterprise development strategy is determined the integration of HACCP system into the operating QMS (Akhmetova, S.O., Fuschi, D. L., Vasiliūnaite, R., 2017).

\section{A technique of creation of integrated quality management system for food enterprise: results and discussions}

\subsection{Development of a project of creation of integrated quality management system for "Raimbek Agro" LLP}

Creation of the IQMS is the complex innovative project directed to increase in efficiency of general management of an organization. Organizationally and methodically development and implementation of a draft of IQMS creation promotes increase in level organizational-technological maturity of processes and the enterprise in a whole and provides introduction of HACCP (Alymbekov K.A., 2003; Yefimov V.V., 2009) system considering branch specifics.

Initially we analysed theoretical and practical aspects of stages of construction and development of QMS and HACCP systems on a basis of studying of scientific-theoretical publications in the area of quality, and also practical experience of introduction and development of these systems.

The analysis of stages of development and introduction of QMS and HACCP showed existence during creation of these systems of the main similar procedures, such as: inspection of the enterprise for the purpose of detection of its readiness for creation of the considered systems; development of documentation structure and introduction of the documentation of these systems; personnel training; carrying out the self-inspection and certified audit. Therefore the approach and stages of works on integration of HACCP system at existence of quality management system are similar to approach during creation of quality management system with accounting of the established distinctions. At building of an algorithm of creation of IQMS we developed a complex of the stages considering specifics of development and introduction of two considered systems. IQMS construction order includes consecutive performance of the following stages: organization of IQMS development, IQMS design, IQMS documenting, inplementation of IQMS, preparation IQMS for certification (fig. 3). 
ENTREPRENEURSHIP AND SUSTAINABILITY ISSUES

ISSN 2345-0282 (online) http://jssidoi.org/jesi/

2019 Volume 6 Number 4 (June)

http://doi.org/10.9770/jesi.2019.6.4(19)

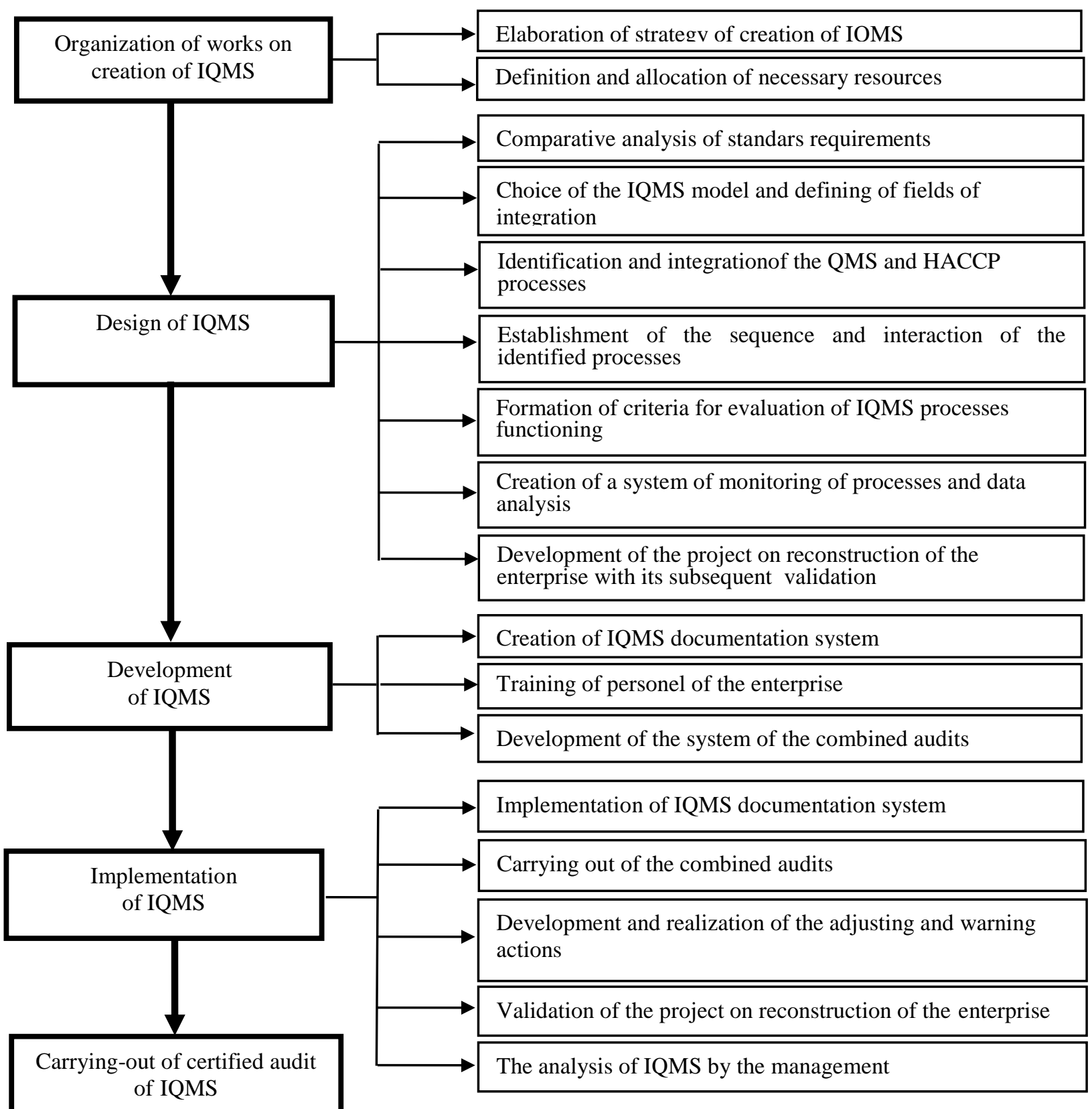

Figure 3. Algorithm of a technique of creation of IQMS

Source: composed by the authors 


\subsection{Formation of a conceptual model of the management system integrating requirements of the international ISO standards of series 9000 and HACCP principles}

Initial stage of IQMS design is the comparative analysis of requirements of the introduced standards, for this purpose for assessment of the possibility of integration of the HACCP system in the operating QMS at the "Raimbek Agro" LLP enterprise we considered structures of the ST RK ISO 9001-2016 and ST RK 1179-2003 standards.

ST RK 1179-2003 submit themselves the system of requirements, recommendations and measures which performance is intended to help the enterprise to organize release of quality products. In distinction from the ISO standards of series 9000, it has concrete branch orientation and is strongly detailed.

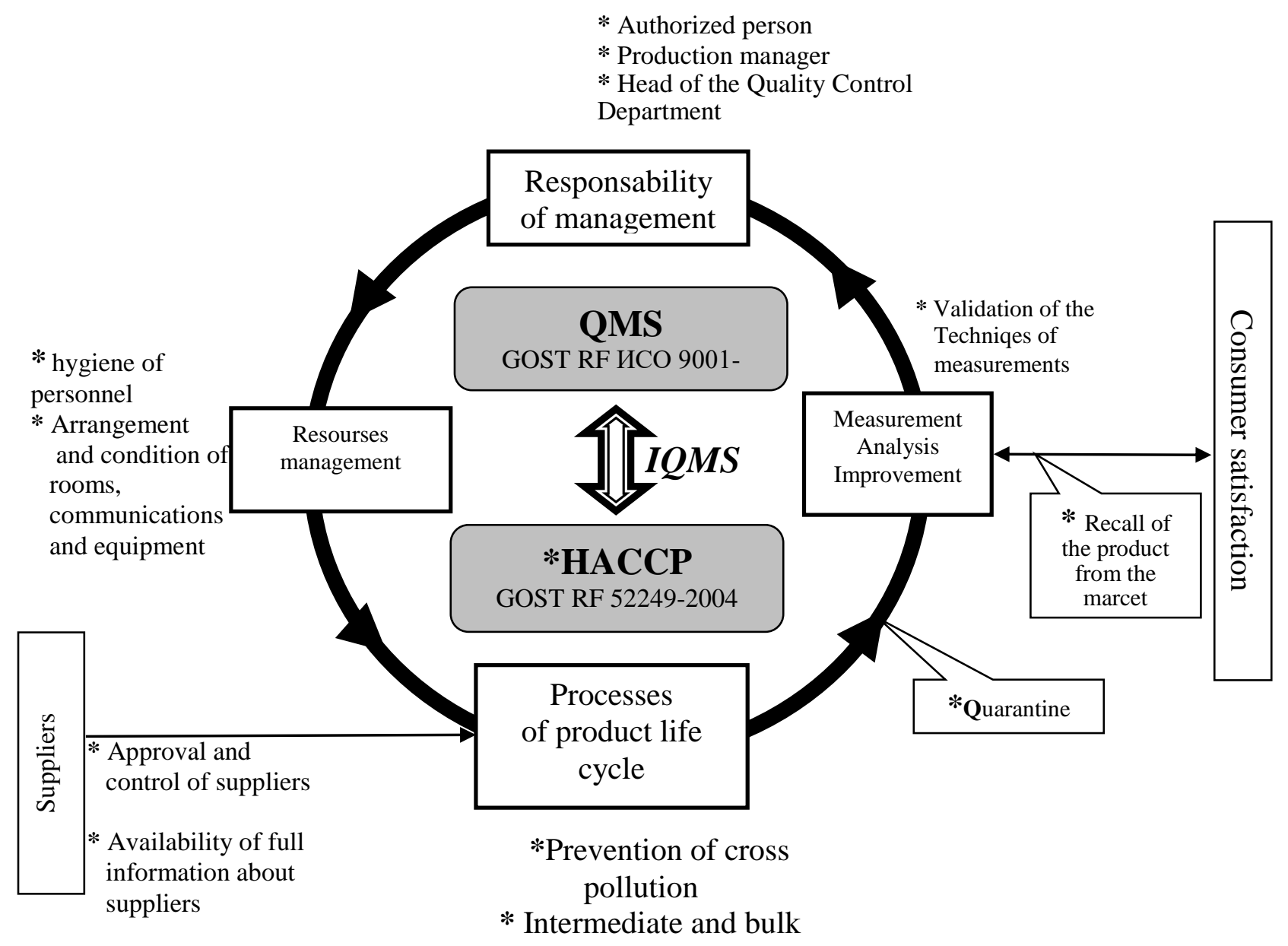

Figure 4. The conceptual Model of a Management System Integrating Requirements of QMS and HACCP Source: composed by the authors 
ENTREPRENEURSHIP AND SUSTAINABILITY ISSUES

ISSN 2345-0282 (online) http://jssidoi.org/jesi/

2019 Volume 6 Number 4 (June)

http://doi.org/10.9770/jesi.2019.6.4(19)

The methodological and ideological proximity is characteristic of the ST RK ISO 9001-2016 and ST RK 11792003 standards. Thus, association of these management systems in IQMS is promoted by proximity of composition and structure of objects of standardization, compatibility of a number of elements and requirements. The universality of methodology and requirements of the ISO 9001 standard allows integrating without special difficulties into the management system of enterprise, the ST RK 1179-2003 standard.

Creation of IQMS assumes formation of the uniform model based on the basic approaches and the principles underlain in the international standards for management within different systems by organic combination of their requirements (Zamyatina O.V., 2006; Ungan Mustafa C., 2006; Yefimov V.V., 2009). Taking into account the formulated requirements the conceptual model of a management system integrating requirements of QMS and HACCP (fig. 4) was created.

The created conceptual model reflects requirements imposed by the international ISO standards of series 9000 and the HACCP rules for quality and safety of food products and allows to minimize the all types of resourceproduction (human, temporary, material, etc.) used during the developing, implementation, certification of IQMS and its further functioning

The choice of a way of creation of IQMS is carried out depending on existence or lack of the functioning management system at the enterprise, features of management systems and their orientation on accounting of requirements of the external environment. Considering the sphere of activity, the size of the enterprise, specific legislative requirements and the available experience in management of the enterprise, we offered the mechanism of creation of the IQMS additive model for the food enterprise "Raimbek Agro" LLP created on a basis of already existing and productively functioning QMS (fig. 5).

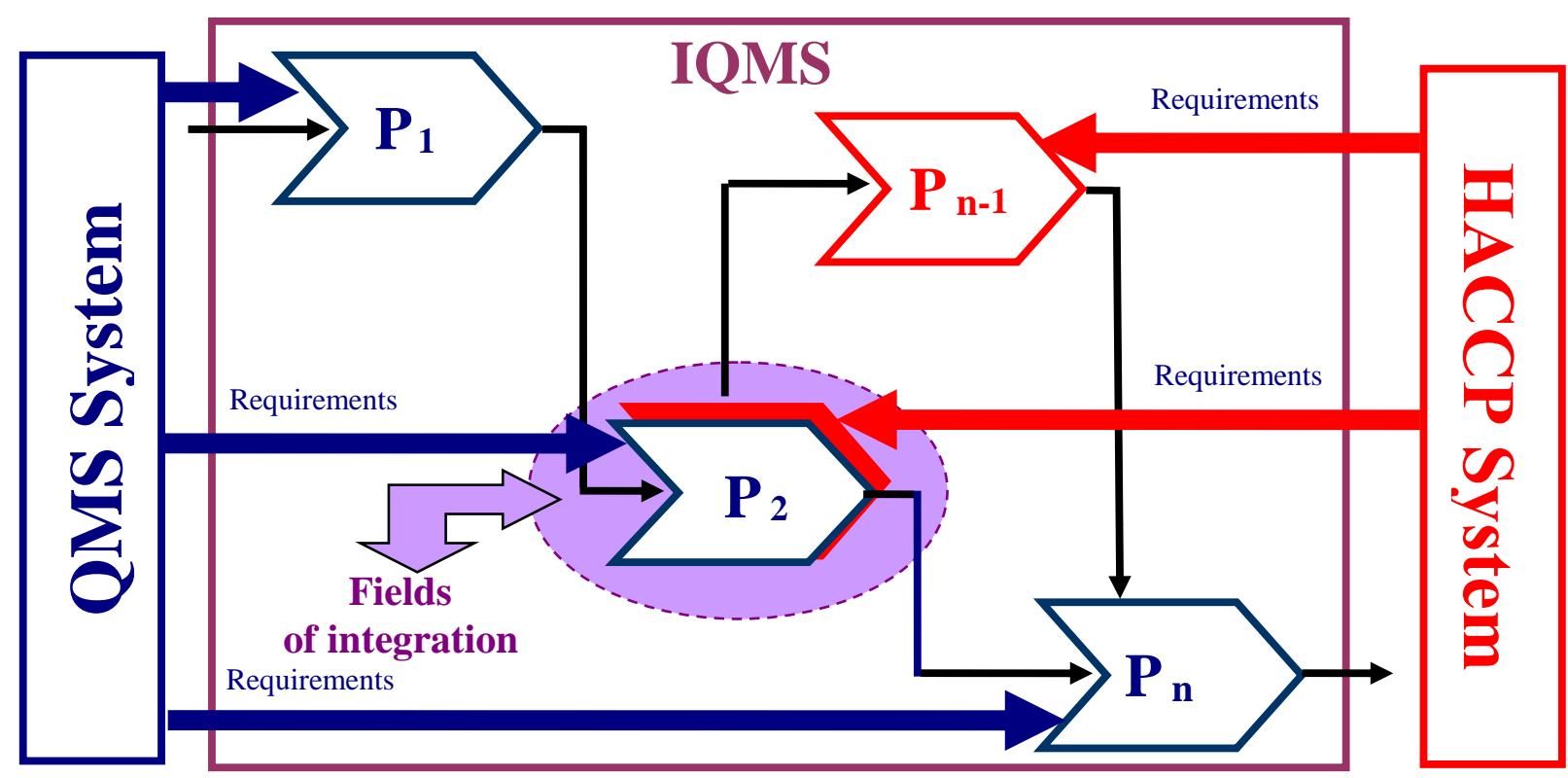

Figure 5. The mechanism of creation of the IQMS additive model Source: composed by the authors 
For realization of the mechanism of creation of additive model it is necessary to define accurately the fields of integration representing by themselves a set of requirements of the considered standards which are characterized by the greatest ideological proximity. With use of the principle of combination of elements the fields of integration are established (fig. 6).

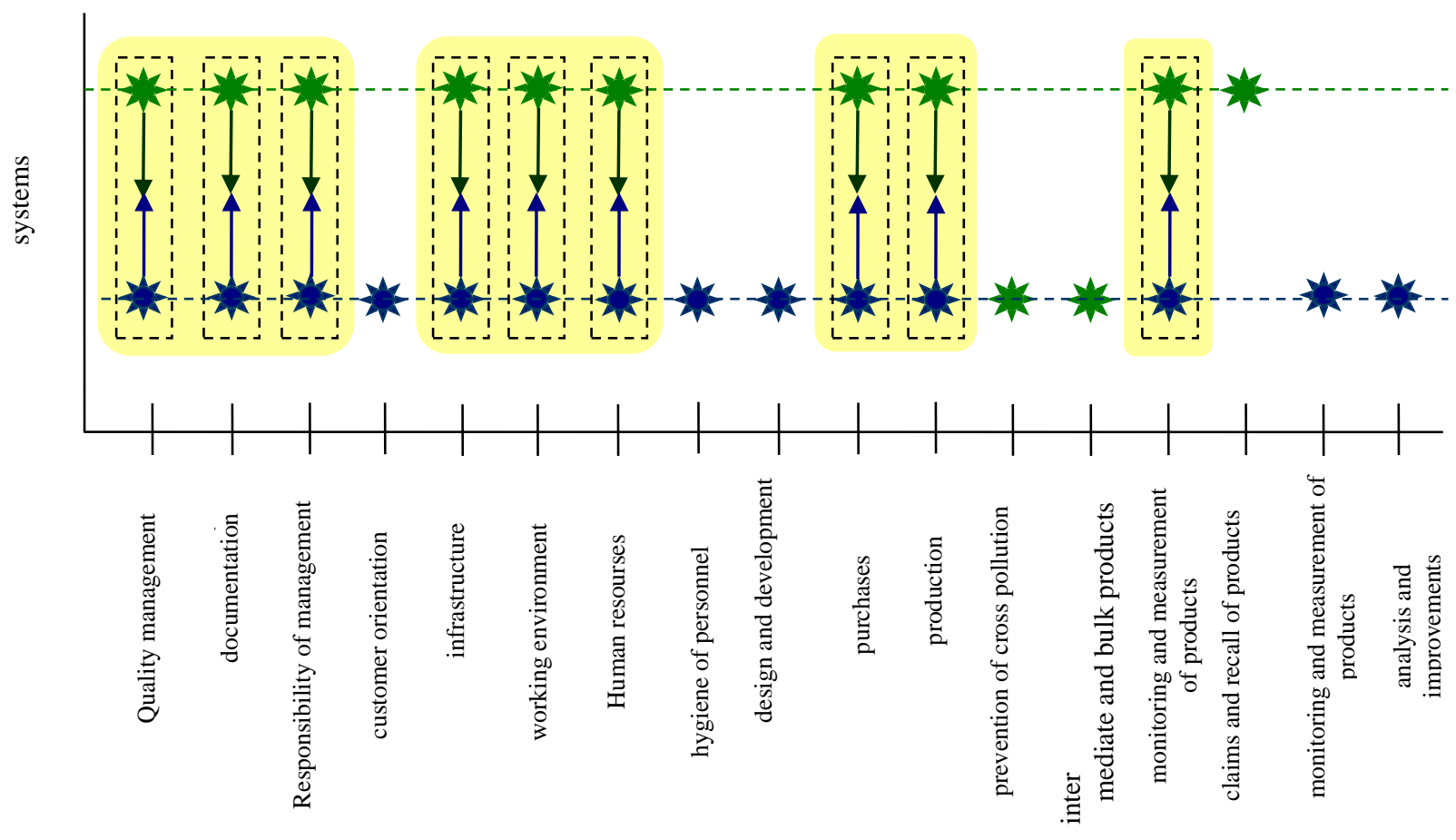

Figure 6. The fields of integration of the QMS and HACCP systems Source: composed by the authors

As a result 9 fields of integration were defined: quality management, documentation, responsibility of the management, infrastructure, production environment, human resources, purchases, production, monitoring and measurement.

\subsection{Decomposition of processes and formation of network of the processes meeting requirements of IQMS}

One of the main problems of design of the integrated management system is the stage of identification and integration of the QMS and HACCP processes, with the subsequent establishment of the sequence and interactions of the identified processes. At decomposition of processes and integration them into the general network of processes of the enterprise is very important to provide an effective use of all types of resources and integrity of perception of the management system by the management and personnel, 
ENTREPRENEURSHIP AND SUSTAINABILITY ISSUES

ISSN 2345-0282 (online) http://jssidoi.org/jesi/

2019 Volume 6 Number 4 (June)

http://doi.org/10.9770/jesi.2019.6.4(19)

an also to exclude duplication of IQMS constituents (Ben B. Graham, 2004; Berzher S., Giyyar S., 2003).

On the basis of earlier defined specific requirements of ST RK 1179-2003 which have to be introduced at the enterprise during creation of IQMS and the established fields of integration the analysis of the processes operating at the "Raimbek Agro" LLP on a subject of establishment of their status in the course of creation of IMS (fig. 7) was carried out.

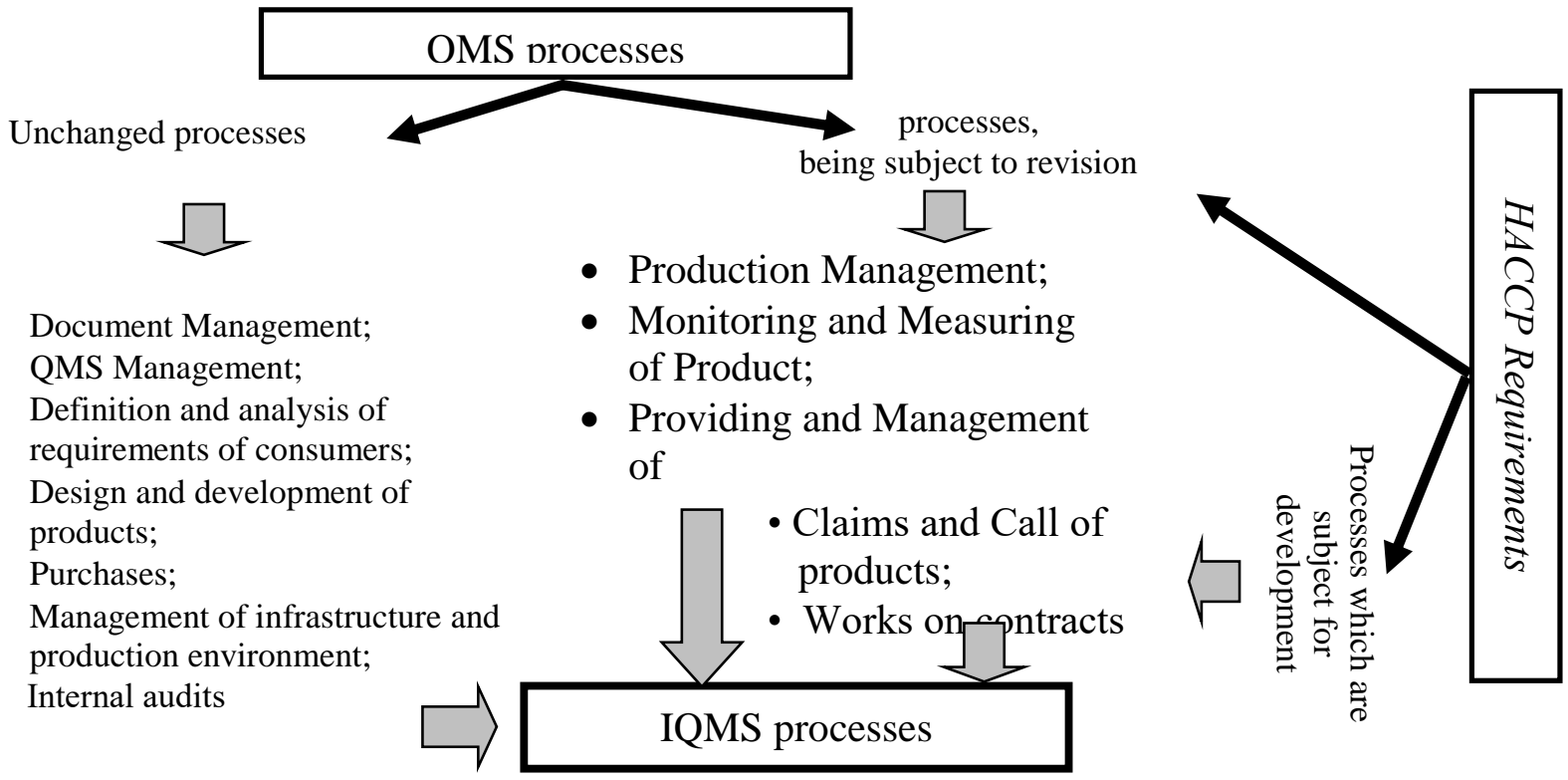

Figure 7. Formation of a structure of IQMS processes

Source: composed by the authors

The process "Document Management" is assepted to leave unchanged owing to analogousness of the requirements of ST RK ISO 9001-2016 and ST RK 1179-2003 specified during creation and work with documents. The essential distinction is in the structure and content of the documents of QMS and HACCP systems that will not be reflected on the considered process in any way.

For the processes which are subject to revision stage-by-stage decomposition of QMS of processes operating in a framework with accounting of specific requirements of the HACCP system which need to be considered for full functioning of IQMS was carried out. The HACCP system establishes tougher requirements for production of goods which is necessary to consider at "Management of Production" process decomposition in IQMS. Thus the following subprocesses "Validation", "Prevention Cross Pollutions" and "Packing" which existence will provide observance of the specific requirements imposed by ST RK 1179-2003 to process "Management of Production" have to be added to this process. 


\section{ENTREPRENEURSHIP AND SUSTAINABILITY ISSUES}

ISSN 2345-0282 (online) http://jssidoi.org/jesi/

2019 Volume 6 Number 4 (June)

http://doi.org/10.9770/jesi.2019.6.4(19)

Taken in account of the aforesaid the scheme of the process "Production Management" in IQMS meeting requirements of two standards is offered: ST RK ISO 9001-2016 and ST RK 1179-2003. The process "Providing and Management of Personnel" in a framework of IQMS is complemented with subprocess "Hygiene of Personnel".

It should be noted that, considering possible potential danger of food products, the ST RK 1179-2003 standard gives a special attention to actions when obtaining claims with the subsequent recall of products. In this regard the process "Claims and Recall of Products", including subprocesses "Investigation of Violations" and "Product recall"” was processed.

For newly created processes requirements of the ST RK 1179-2003 standard, which establishes approach to the organization of such works and regulates the sequence of actions were taken for basic. For the processes having the status "revision" and "development" criteria for evaluation of their functioning and methods of measurement were also offered. As a result of integration of processes the uniform network of the backbone processes operating in IQMS is created.

\section{Conclusions}

Results of the conducted theoretical researches and their practical realization allow making the following main conclusions:

1 On the basis of the carried-out analysis of trends of development of modern management an expediency of creation of the integrated quality management system for food enterprise reflecting branch specifics is established;

2 Theoretical and practical aspects of creation of HACCP and QMS systems are analysed, the technique of creation of the integrated quality management system is offered and the innovative project "Construction and Implementation of the Raimbek Agro LLP IQMS", including the purpose, objectives, motives and description of stages of realization of the project is developed;

3 On the basis of the analysis of the international ISO 9001-2015 standard (ST RK ISO 9001-2016) and the HACCP rules (ST RK 1179-2003) and the established degrees of compatibility of their requirements the conceptual model of IQMS reflecting branch specifics of the food enterprise is offered;

4 On the basis of the revealed fields of integration of the HACCP and QMS systems a composite design of processes is carried out and indicators of effectiveness of processes and methods of their measurement are developed;

5 The network of processes of the "Raimbek Agro" LLP IQMS according to the offered mechanism of creation of the additive model is formed.

6 Application of the process approach at creation of IQMS taking in account the branch requirements of HACCP allowed to allocate and identify the processes operating in the QMS and HACCP systems. The analysis of the processes and subprocesses of both considered systems showed basic compatibility of QMS and HACCP owing to existence of similar processes and subprocesses, an also allowed to create uniform network of the 


\section{ENTREPRENEURSHIP AND SUSTAINABILITY ISSUES}

ISSN 2345-0282 (online) http://jssidoi.org/jesi/

2019 Volume 6 Number 4 (June)

http://doi.org/10.9770/jesi.2019.6.4(19)

interconnected and interdependent processes, at the correct management of which effective and productive management of IQMS can be provided.

\section{References}

Akhmetova, S.O., Fuschi, D. L., Vasiliūnaitè, R. (2017). Towards food safety: quality management peculiarities, Journal of Security and Sustainability Issues 6(3): 513-522. http://dx.doi.org/10.9770/jssi.2017.6.3(15)

Akhmetova, S.O., Omarova, A.A. (2014), Development of a technique of creation of the integrated quality management system of the food enterprise on the example of the Raimbek Agro company. V Intern. Scientific and Pract. Conf. "Agricultural Sciences and Agroindustrial Complex at the turn of the Century", Novosibirsk, March 21, 2014, pp. 286-296.

Alymbekov, K.A. (2003). The integrated quality management system: branch specifics, Journal 'Standards and Quality’2: 64-65.

Avstriyevsky A.N., Kantare V.M., Surkov I.V. (2007). Quality management at the enterprises for food and processing industry. Novosibirsk: Sib. Univ. publ. house. 268 pages. https://www.twirpx.com/file/1710186/

Ben B. Graham. (2004). Detail process charting: speaking the language of process - John Wiley \& Sons Ltd, 2004. - 208 p.

Berzher S., Giyyar S. (2003). Graphic description of processes. Technique and Technical Means. Translation from french. - N. Novgorod: SMTs "Priority", 2003.-250 p. zipsites.ru/me/it/Sedrik_Berzher...

Bojkovska K., Tomovska J., Mohammad Ali Shariati (2014). Conteporary Quality Management System Elements in the Food Industry, VestnikOrelGAU 6(51): 48-50. cyberleninka.ru/article/n/...

Chris Bamber, John Sharp, Mick Hides. (2002). The role of the maintenance organization in an integrated management system, Managerial Auditing Journal 17(1/2): 20-25. ijsrr.org/pdf/155.pdf

Conti, T. (2005), Quality in the XXI century. A quality role in ensuring competitiveness and a sustainable development. - M.: RIA "Standards and Quality", 280 p.

David K. Watkins. (2006). Reflection on the future of quality, Quality Progress 13(1): 23-28.

FMCG-PP-6001 Quality manual of Raimbek Agro LLP

ISO 9001:2015. Quality management systems - Requirements https://www.iso.org/standard/45481.html

Lafta J.K. (2007). Efficiency of management of the organization. Manual. M.: Russian business literature. 237 p. https://www.twirpx.com/file/549019/

Maximov, Yu.A., Papkov, V.I. (2003). QMS as means of increase of competitiveness and efficiency of the enterprise, Quality Management Methods 11: 9-14.

Rodionova Yu.A. (2013). Organization of assessment and monitoring of a quality management system of the enterprise. Abstract of the dissertation, St. Petersburg. 18 p.

Shalaev A.P. (2006). Industry standards on a quality management system: prospects of development, Standards and Quality 5: 62-64. http://library.karelia.ru/catalog/nlibr

ST RK 1179-2003. Quality System. Foodstuff Quality Management on the basis of the principles of HACCP. General Provisions. info@naceks.kz

ST RК ИСО 9001-2016 Quality management systems - Requirements. https://www.iso.org/standard/45481.html

Svitkin, M.Z. (2004).The Integrated Management Systems, Standards and Quality 2: 6-61. journal.tltsu.ru/rus/index.php/... 
ENTREPRENEURSHIP AND SUSTAINABILITY ISSUES

ISSN 2345-0282 (online) http://jssidoi.org/jesi/

2019 Volume 6 Number 4 (June)

http://doi.org/10.9770/jesi.2019.6.4(19)

Tvaronavičienè, M., Tarkhanova, E., \& Durglishvili, N. (2018). Sustainable economic growth and innovative development of educational systems, Journal of International Studies 11(1): 236-244. https://doi.org/10.14254/2071-8330.2018/11-1/19

Ungan Mustafa C. (2006). Standardization through process documentation, Business Process Management Journal 12(2): $135-148$.

Yefimov V.V. (2009). Means and methods of quality management: manual. M.: KNORUS. 232 p. http://www.docplayer.ru/56430230

Zamyatina, O.V. (2006). Safety of food and medical equipment, Quality control of food products based on the principles of HACCP. Translation from English - M.: RIA "Standards and Quality", 2006. - 232 p. hse.ru/data/2014/05/07/...

\section{Short biographical note about the contributors:}

Saule Ospandiyarovna AKHMETOVA is the Associate Professor in Chemical Engineering of Almaty Technological University, Almaty, Kazakhstan. PhD in Technology of Inorganic Substances. Chartered Engineer-Chemist-Technologist (CEng), Researcher and Academic Staff of Higher Education Institutions with almost 35 year experience, a track record of over 90 publications, including monograph "Processing of low-grade phosphorites", 8 USSR and RK patents, scientific papers and presentations at the conferences, acquisition of 5 projects. A Scholar of the International "Bolashak" Programme of the President of the Republic of Kazakhstan 2013-2014, Owner of the grant of the Ministry of Education and Science of the Republic of Kazakhstan "The Best Teacher of Higher Education Institutions - 2018". Research areas: Complex processing of low-quality phosphatic raw materials into important products of economic value; Analysis and improvement of QMS of the enterprises for food industry of RK; Food Security; Ecology.

ORCID ID: orcid.org/0000-0001-7287-766X

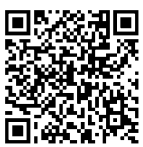

Lyazzat Kemerbekovna BAIBOLOVA is the Professor in Technology of food industry and Vice-Rector for Educational Affairs of Almaty Technological University, Almaty, Kazakhstan. Dr of Sciense in production technology of meat, dairy, fish products and refrigeration industries. Her scientific and pedagogical experience is more than 25 years, a track record of 250 publications, including 3 textbooks, 3 monograph, 11 USSR and RK patents, scientific papers and presentations at the conferences. Acquisition and advisor of 5 projects: 1 international and 4 Republican scientific projects finded by RK and Ukraine (the partner scientific program). Area of scientific interests: production of functional food products and dietary supplements, development of vegetable oils from oilseeds by cold pressing, food security, ecology.

ORCID ID: orcid.org/0000-0002-8118-1581

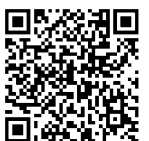

Mira Serikovna SERIKKYZY is a PhD in Technology of food products, Senior Lecturer at the Department «Safety and quality of food products» of Almaty Technological University. Her scientific and pedagogical experience is about 15 years, she has published 35 works, including 3 patents of the Republic of Kazakhstan, 3 manuals, scientific papers and presentations at the conferences. Research area: Investigation of quality and safety of meat products; Development of technology of meat products with low sodium nitrite content; Development of guidelines for reducing risk in meat production.

ORCID ID: orcid.org/0000-0002-5110-9570 
ENTREPRENEURSHIP AND SUSTAINABILITY ISSUES

ISSN 2345-0282 (online) http://jssidoi.org/jesi/

2019 Volume 6 Number 4 (June)

http://doi.org/10.9770/jesi.2019.6.4(19)

Register for an ORCID ID:

https://orcid.org/register

Copyright (C) 2019 by author(s) and VsI Entrepreneurship and Sustainability Center

This work is licensed under the Creative Commons Attribution International License (CC BY).

http://creativecommons.org/licenses/by/4.0/

(C) (i) Open Access 